\title{
Bir Haber Toplama Tekniği: Video Habercilik
}

\author{
Emrah Semih Koșar ${ }^{1}$
}

Öz

\begin{abstract}
Habercilik, 80'lerde televizyon yayınları ve 90'larda internet teknolojilerindeki gelişmeler ile birlikte hızlı bir değişim ve dönüşüm geçirmiştir. Günümüzde özellikle mobil teknolojiler, yeni haber toplama tekniklerini tartışmaya açmaktadır. Bu doğrultuda çalışma, dünyada yeni bir haber toplama tekniği olarak video habercilik kavramını konu edinmektedir. Video habercilik ile ilgili veriler literatür taramasıyla elde edilmiş, ardından Türkiye'den iki video haber örneği çözümlenmiştir. Araşırma nitel ve betimleyici bir çalışmadır.
\end{abstract}

Anahtar Kelimeler: Video, Video Haber, Haber Videoları.

\section{A Type of News Gathering Technique: Video Journalism}

\begin{abstract}
Journalism has rapidly changed and transformed by television broadcasts in the 80 s and development of internet technologies in the 90s. Today, particularly mobile technologies have created debates on new techniques regarding newsgathering. In this context, this study aims to disclose news videos and video journalism as a new tool of newsgathering throughout the world. The information on video journalism is based on literature, and following the literature research, two examples of video news have been analyzed. The study is a qualitative and descriptive one.
\end{abstract}

Keywords: Video, Video Journalism, News Videos. 


\section{Giriș}

j Ik televizyon yayını 1936 yılında İngiltere'de gerçekleşmiş; 1950'lerden itibaren televizyon, tüm dünyaya yayılmıştır. 1960'lı yıllar ise, televizyonun altın çağı olarak kabul edilmiştir. Bu yıllarda video teknolojisinin ortaya çıkışıyla televizyon yayıncılığı, yeni teknik imkanlara kavuşmuş; bu imkanlar zaman yönetimi ve mali açılardan yayıncılara önemli kazanımlar sağlamıştır. 60 'ların siyasi ve ekonomik koşulları; sanat ve müzikte sadelik ve nesnelliği ön plana çıkaran minimalist anlayış, televizyon yayıncılığı ve televizyon haberciliğini de etkilemiş; özellikle ABD'de yerel televizyonlar, bazı yapısal değişikliklere giderek yeni arayışlar içine girmiştir. Bu çerçevede alanda, haberin çekimiyle birlikte sunumunu da kendi yapan; ardından topladığı görüntüleri yine kendi montajlayan muhabirler ortaya çıkmaya başlamıştır. Video habercilik (Video journalism) olarak adlandırılan bu yeni habercilik anlayışı, 60'lardan $80^{\prime} l e r e ~ k a d a r$ yerel televizyonlar düzeyinde sınırlı bir alanda varlık gösterirken; 80'lerden itibaren savaş muhabirliğinin ve uydu yayıncılığı gibi yeni iletişim teknolojilerinin öne çıkışıyla, ana akım televizyon haberciliğinde de yer edinmeye

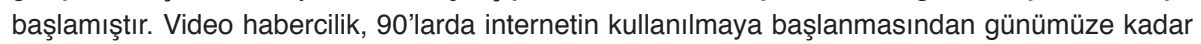
geçen sürede giderek yaygınlaşmış ve habercilik türleri içinde yerini almıştır (Thorand, 2006: 6-11; Gyimah, 2010; Rosenblum, 2006).

Bu çalışmada, ülkemizde yapılmış olan habercilikle ilgili araştırma ve tartışmalarda henüz yer almadığı gözlemlenen video habercilik kavramı ele alınmıştır. İlk olarak haber kavramının ortaya çıkışı ile haber toplama ve yayma teknikleri tarihsel olarak ortaya konmuştur. Ardından, söz konusu habercilik türünün ortaya çıkışına zemin hazırlayan ekonomik, siyasi ve teknolojik koşullar ortaya konarak, bu habercilik biçimiyle ilgili genel bir çerçeve çizilmeye çalışılmıştır. Bu çerçeve dahilinde, Türkiye'den Anadolu Ajansı ve Hürriyet gazetesinin internet sitelerinin video sayfalarında yer alan birer video haberin çözümlemesi yapılmışıı. Çalışma kapsamında, ülkemizde haber içerikli internet sitelerinde yer alan video haberlerin, dünya ölçeğindeki benzerlerinden oldukça farklı ve kavramın içini doldurmaktan bir hayli uzak olduğu varsayımından hareketle, dünyadaki ve ülkemizdeki video habercilik biçimi ve anlayışlarının karşılaştırmalı olarak ortaya konulması amaçlanmıştır. Yapılan haber çözümlemelerinden elde edilen bulgulara göre, Türkiye'deki haber sitelerinde "video haber" ya da "video galeri" bağlantıları altında yayınlanan içeriklerin, dünya ölçeğinde yürürlükte olan benzer video habercilik biçimlerinden uzak bir anlayışta olduğu saptanmıştır.

\section{Haber Toplama ve Yayma Tekniklerinin Tarihsel Gelișimi}

Gazetecilik 19. Yüzyılda kapitalizmin gelişimiyle ortaya çıkmıştır. Gazeteciliğin kökeninde ise Avrupa'da ortaçağın sonlarında ortaya çıkan haber mektupları yatmaktadır (Tokgöz, 2012: 63). Mağara duvarları ve ağaç gövdelerinde bulunan insan ve hayvan figürleriyle birlikte sözlü geleneği takip eden yazılı ürünler olarak kil tabletler, el yazmaları ve kuşkusuz Gutenberg'in keşfiyle ortaya çıkan ürünler, habercilik ve gazeteciliğin öncüleri olarak kabul edilmektedir (Cavalier, 2004: 1522).

Halk için ilginç olan, halkı ilgilendiren haberleri ve olayları toplama, yazma ve bildirmeyle ilgili bir meslek (Mutlu, 2004:107) olarak tanımlanan gazetecilik, 20. Yüzyılda kitlesel bir hale dönüşmüştür. İletişim araçlarının gelişimi bu yüzyılda da devam etmiş; gazeteyle birlikte temel haber alma kaynaklarına önce radyo ve ardından televizyon eklenmiştir.

1890'da Fransız Edouard Branly radyo iletkenini bularak ilk alıcıyı ortaya koymuştur. Takip eden on yıl boyunca Rus Popov, İtalyan Marconi, Amerikalı Forest'ın buluşa yaptıkları katkılar ve 
1906 'da Fessenden'in ilk uzun menzilli radyo yayınını gerçekleştirmesiyle sesin, iki nokta arasında taşınması mümkün hale gelmiştir. General Ferrie'nin, 1921'de Eyfel Kulesi'ne yerleştirilen radyo vericisi aracıı̆̆ıyla gerçekleştirdiği ilk düzenli Fransız yayınıyla radyo, iletişim araçları arasına katılmıştır. Bu düzenli yayınlar sözlü basının da ilk örneklerini vermiş̧ir. Yayınlarda ilk olarak hava durumu, ardından tarım ürünlerini içeren borsa verileri hakkında bilgiler aktarılmışıı (Cavalier, 2004: 129-130). 1922, İngiltere'de BBC'nin kamu yayıncılığına, Fransa'nın ise özel radyo yayıncılığına başladığı yıl olmuştur. Gazetelerle başlayan habercilik anlayışı radyoda devam etmiş; ancak her iletişim aracının kendine has yapısal özellikleri burada da devreye girmiştir. Radyoculukta haber yazım ve aktarım teknikleri temelde gazetecilikle benzer özellikler gösterse de, sesin kullanımı ve kayıt teknolojilerinin kullanımıyla spikerin okuduğu habere, daha önce alanda kaydedilmiş sesler de eşlik etmiştir. Radyo, 1900'lü yıllardan 50'lere kadar geçen sürede, özellikle iki dünya savaşı boyunca haber alma işlevini yerine getirmede temel öneme sahip olmuştur. Sesin ve radyonun o dönemlerdeki gücünü ortaya koyması bakımından, sonraları sinemada kendine önemli bir yer edinen Orson Welles'in, Amerikan CBS radyosunda Dünyalar Savaşı adıyla sunduğu radyo tiyatrosu önemlidir. Oyunun bir bölümünde Marsılıar uzay araçlarıyla dünyaya inmektedir. Oyunun bu bölümünde hararetli bir duyuru yapmakta olan Welles, radyolarını yeni açanlar ya da başka istasyonlardan CBS'i dinlemeye geçenler tarafından yanlış anlaşıımıştır. Büyük bir panikle halk sokaklara fırlamış ve kitlesel göçler başlamıştır. Radyonun bu tartışılmaz gücü, savaş öncesi ve savaş sırasında etkin bir propaganda aracı olarak kullanılmasına yol açmışıı (Cavalier, 2004: 131).

Televizyonun keşfi ise 1880 'lü yıllara kadar uzanmaktadır. Alman mühendis Paul Nipkow, 1884 yılında geliştirdiği basit mekanik bir düzenek ile fotoğrafik görüntüleri elektrik sinyallerine dönüştürmeyi başarmıştır. Nipkow diski olarak anılan düzenek, bilinen televizyon sistemlerinin atası kabul edilmekle birlikte, birkaç deneme dışında düzgün çalışmamış ve istenen sonucu vermemiştir (Barnouw, 1990: 5). 1925 yılında İskoç mucit John Logie Baird, Televisor adını verdiği bir sistem geliştirmiştir. Baird, Nipkow'un diskini kullanmış ve hareketli görüntüleri elektrik sinyallerine dönüştürerek iletmeyi başarmıştır (Barnouw, 1990: 49). İngiltere'de o dönemde radyo yayıncılığı yapmakta olan BBC, sistemle ilgilenmiş ve 1929 yılından itibaren deneme yayınlarına başlamıştır. İngiltere'de 1929 ile 1937 yılları arasında yaklaşık 2000 televizyon satılmıştır. Denemelerle geçen bu yıllar sonunda, 2 Kasım 1936 tarihinde, bilinen anlamda ilk televizyon yayıncıı̆̆ı yine BBC tarafından gerçekleştirilmiştir. Bazı sinemacılar, sinemaya öykünen televizyonu bir rakip olarak görmüşlerdir. ABD'de dönemin Fox film şirketi başkanı Darryl Zanuck, televizyonun hiçbir şekilde piyasada tutunamayacağını, insanların kontrplak bir kutuya her gece bakmaktan er ya da geç sıkılacaklarını iddia etmiştir (Covey, 1998: 22). Ne var ki halkın, radyonun görüntülüsü olarak tanıdığı televizyon, çok geçmeden hızla tüm dünyaya yayılmıştır. 50’lerde renkli yayına geçilmesiyle birlikte televizyon satışları artmış; dolayısıyla, izleyici sayısında da büyük bir artış kaydedilmiştir. Televizyonda da radyoda olduğu gibi haberleri spiker sunmaktadır. Televizyonda aktarılan habere yazı, şekil, resim, fotoğraf ve hareketli görüntülerden oluşan grafiklerle, haberin görüntülü kayıtları ve kaydedilmiş sesler eşlik etmektedir (Tokgöz, 2012: 427).

90'lardan itibaren haber medyası internetin gelişimiyle farklı bir noktaya taşınmıştır. Kullanıcı gazeteden okuyarak; radyodan dinleyerek; televizyondan ise izleyerek gerçekleştirdiği haber alma faaliyetini aynı anda tek bir mecra üzerinde, yani internette sürdürmeye başlamıştır. Günümüzde mobil cihazların katettiği yol da göz önüne alındığında, zaman ve mekan gözetmeksizin habere her an ulaşmak mümkün hale gelmiştir. comScore'un ${ }^{2}$ Aralık 2012 verilerine göre, başlangıçta sadece ABD ile sınırlı kalan internet kullanımı; bugün, $A B D$ dışında \% 87'lik bir paya ulaşmıştır (Ntv.com. tr, 2013). 2013 yılı verilerine göre, 2009 yılından başlayarak ABD'de televizyon izleyicisi sürekli 
bir azalma göstermiştir. İnternet kullanımıysa, 2010 yılında bir önceki yıla kıyasla yükselmiş ve takip eden iki yıl boyunca aynı seviyede kalarak, 2013 yılında 2009 yılındaki seviyeye gerilemiştir. Aynı verilere göre mobil internet kullanımı 2009 yılında \% 4 seviyesindeyken, 2013 yılında 5 kat artarak \% 20 seviyesine ulaşmış ve masaüstü internet kullanımını geride bırakmıştır. Bir başka veri ise, tüm dünyada internet kullanıcılarının, daha çok videolarla ilgili faaliyetlerle (kaydetme, izleme, paylaşma) zaman geçirdiklerini ortaya koymuştur. 2013 itibariyle aylık 1 terabaytlık video trafiğinin, 2017 yılında 8 terabayta kadar yükselmesi öngörülmektedir (Genel Gündem, 2013; Cisco, 2013). İnternette video platformlarının öncüsü olarak kabul edilen Youtube, daha önce özel kişi ve kuruluşlara sağladığı canlı yayın hizmetini 2014'ten itibaren tüm kullanıcılara sunma kararı almıştır (Öztürk, 2013). Yine 2014 yılında Youtube'un, yüksek çözünürlüklü video yayın hizmetine, 4K ultra yüksek çözünürlüklü; yani 4096×2160 ve 3840x2160 boyutlu video yayınlarını da ekleyeceği duyurulmuş (Ntv.com.tr, 2014), 2014 Haziran ayında site, saniyede 60 kare hızında 4K video testlerine başlamıştır (Stuart, 2014). Ekim 2014'ten itibariyle testler sonuçlanmış, saniyede 60 kare 4K çözünürlüklü videolar, sitede yayın standartlarından biri haline gelmiştir (Kumparak, 2014). Şubat 2015 ’te Türkiye'de TRT, 4K ultra yüksek çözünürlüklü test yayınlarına başladı (Milliyet, 2015). 2010 yılında ücretsiz fotoğraf paylaşım programı olarak kurulan Instagram, Haziran 2013'ten itibaren kullanıcılarına, 15 saniyeyle sınırlandııılmış videolarını da paylaşıma açma imkanı sunmuştur. Son yıllarda internet, sosyal medya ve mobil cihazların gelişimiyle, kullanıcı tarafından üretilen fotoğraf ve video paylaşımı öne çıkmıştır. İnternetin eğlence tarafında bunlar olurken, habercilikte de video türü içerik üretiminden, geniş ve artan ölçekte yararlanılmaktadır.

\section{Video Teknolojisinin Gelișimi}

Video sözcügünün kökeni, bakmak anlamına gelen, Latince videre fiiline dayanmaktadır. Video ise görüyorum anlamına gelmektedir (oxforddictionaries.com, 2014). Terim, hareketli görüntülerin elektronik bir ortama kaydedilmesi, kopyalanması, gösterimi ve saklanmasını içermektedir. Video sisteminin başlangıcı televizyonla ilgili çalışmaların başlangııına dayanmaktadır. 1926 televizyonun keşfini tamamlayan John Logie Baird, aynı yıl yine kendi geliştirdiği video kayıt sistemi için phonovision adıyla patent başvurusunda bulunmuştur. 1928 yılında kayıt cihazı phonovisor, cihazın kayıt için kullanacağı ortam ise phonovision disc adıyla tescillenmiştir. ${ }^{3}$ 1930'larda ev tipi ses kayıt cihazları ortaya çıkmış, 1934'te ilk kez halkın da kullanımına sunulan video disk piyasaya sürülmüştür. Sınırlı çizgi film görüntülerinden oluşan diskler televisor adı verilen ve son kullanııının rahatıkla ulaşamayacağı sistemlerde oynatılabilmiştir. 1936 yılında BBC düzenli olarak televizyon yayınına başlamış ancak oldukça önemli sorunlar da ortaya çıkmıştır. Yayınların tamamı canlı olduğundan bir program tekrar edilmek istendiğinde ikinci bir canlı yayınla program bir kez daha yapılmak durumunda kalınmıştır. İngiltere'de telerecording olarak da bilinen kinescope adlı aygıt, televizyon yayınlarının 16 ya da 35 milimetre filmlerde muhafaza edilmesi için tek yol olmuştur. Ne var ki film teknolojisi o yıllarda televizyonculuk için oldukça maliyetli olduğundan, bu yola gidilmiştir. Sorun sadece maliyet de değildir. 16 ve $35 \mathrm{~mm}$. sinema formatları televizyon ekranında iyi sonuç vermemiştir. Görüntülerde kayıp ve bozulma yoğundur. Görüntülerin televizyonda düzgün bir şekilde gösterilmesi için gerekli olan format dönüşümleri de zaman ve para kaybını artırmıştır. Böyle bir ortamda alternatif bir kayıt teknolojisine kesinkes intiyaç duyulmuştur. Bu ihtiyacın karşılanması noktasında geliştiriciler manyetik karbon bantlara yönelmişlerdir. BBC'nin kendi bünyesinde yürüttüğü çalışmalar ve daha sonraları Dolby'nin kurucusu olarak anılacak olan Ray Dolby ve 3M'in ısrarlı çalışmaları; 1955 'te Ampex'den Charles Ginsburg'un, kullanımı oldukça kolay, ilk video kayıt ve oynatma cihazıyla

3 Baird, Phonovision Disc'lere yaptığı kayıtları hiçbir zaman sergilememiştir. Hasara uğramamış kayıtlar, araştırmacı Don McLean tarafından dijital ortama aktarılarak www.tvdawn.com adresinde sergilenmektedir. 
birlikte video ekranını (monitor) geliştirmesiyle sonuçlanmıştır. Cihazın ve cihazda kullanılan kayıt bandının maliyeti, kinescope ile kıyaslandığında oldukça düşmüştür (Elen, 2003). Ampex o yıllardan itibaren, televizyon ve radyo kayıt teknolojilerinde endüstri standartlarını belirleyen bir kuruluş haline gelmiştir. Televizyon programlarının video sistemleriyle kaydedilip yeniden oynatılmasıyla henüz sorunların bitmediği de görülmüştür. Sistem sinema filmine benzer bir kolaylıkta montaj imkanı sunmamaktadır. Montaj sorununun üstesinden gelmek için bir kez daha kinescope kullanımına yönelinmiş; bu doğrultuda ilk kez 1967 yılında sistemler arası transferler eşleme-senkron problemlerinin önüne geçmek için timecode kullanımına geçilmiştir. Takip eden yıllar bilgisayar temelli montaj setlerinin ortaya çıktığı yıllar olmuştur. 1960’lardan başlayarak son kullanıcıya yönelik video kayıt ve oynatıcıları Philips ve Sony etiketleriyle piyasaya sunulmuştur. 1976 yılında JVC tarafından piyasaya sürülen VHS formatlı cihazlar bugün hâlâ kullanılmaktadır (Elen, 2003). Yayın standartlarında görüntü üreten video kameraların gelişimi 1980'lerde mümkün hale gelmiş, takip eden yıllarda analog kayıttan dijitale doğru bir dönüşüm yaşanmıştır. Son kullanıcı için yüksek maliyetli bu teknolojiler, ancak $90^{\prime}$ ların ortalarında uygun bir fiyat seviyesine gelebilmiştir. Günümüzde ise tamamen dijital bir hale gelerek, manyetik band teknolojisinden bağımsız olarak sabit, optik ve/veya taşınabilir disk sürücüler ve sunucularda depolanan videolar, düşük maliyetli bilgisayar sistemleri ve hatta mobil cihazlarda bile montajlanıp yayınlanabilir hale getirilebilmektedir.

\section{Video Haberciliğin Ortaya Çıkıșı}

Günümüzde Toshiba bünyesinde faaliyetlerine devam eden Ikegami'nin, 1962 yılında piyasaya sürdüğü ilk taşınabilir televizyon kamerası, hem televizyonculukta hem de televizyon haberciliğinde bir dönüm noktası olmuştur. 1960'lar aynı zamanda, dünyada önemli değişim ve dönüşümlerin de yaşandığı yıllardır. 1960'lar, otoriteye duyulan güvensizlik ve ona karşı çıkış üzerine temellenen karşı-kültürün ortaya çıktığı bir dönemdir (Bordwell ve Thompson, 2012: 359). Fordist ve refah devleti döneminde çocukluğunu yaşamış bir kuşağın beğeni ve anlayışları bu dönemde farklılaşmış; sisteme karşı hoşnutsuzluklarını dile getirmeye başlamışlardır (Şimşek, 2005: 22). 1960'lar, son kullanıcının hizmetine 90'larda sunulan internetin, ABD Savunma Bakanlığı Ileri Araştırma Projeleri Kurumu (DARPA: US Defence Department Advanced Research Projects Agency) bünyesindeki bilimadamlarının olası bir nükleer savaşta Sovyet zaferini ya da Amerikan iletişim ağlarının çökertilmesini önlemeye yönelik çalışmalarından doğduğu yıllardır (Castells, 2010: 6). Bu doğrultuda 1960'lar, toplumların, Daniel Bell ve Alvin Toffler gibi birkaç sosyolog tarafından sanayi sonrası ve enformasyon toplumu olarak nitelendirilmeye başlandığı yıllardır. Sonrasında bu toplumlar, 1973 yılında büyük petrol şokuyla karşı karşıya kalacaklardır (Şimşek, 2005: 20-21). Bu şoktan sadece beş yıl önce Paris'te üniversite gençliği tutucu yönetime karşı harekete geçmiş, Fransa genelinde ayaklanmalar ve grevler başlamıştır. Bu eylemlerin merkezinde yer alan "küçük güzeldir" sloganı 1960'ların siyasi, toplumsal ve ekonomik atmosferiyle gündelik yaşam pratiklerinin tanımlanması açısından oldukça önemlidir. Örneğin mini etek, Galli tasarımcı Mary Quant tarafından bu yıllarda tasarlanmıştır. İngiliz yapımı Mini marka otomobiller 1960 'ların sembolü olmuştur. 1965 'te DEC tarafından piyasaya sürülen DECPDP-8 model bilgisayar, ticari başarıya ulaşan ilk mini bilgisayar olmuştur (DEC's Blockbuster: The PDP-8, 2000). Modern sanat ve müzikte sadelik ve nesnelliğin ön plana çıkarıldığı Minimalist Akım 1960'ların başında ortaya çıkmıştır. Avrupa, özellikle Fransız sinemasında 1950'lerde ortaya çıkan minimalist ve yönetmenin filmin her aşamasında bizzat yer aldığı Auteur Sineması, olgunluk dönemi ürünlerini 1960'larda vermiştir. Önceki bölümde belirtildiği gibi 1960'lar, ilk kullanımı kolay video kaydedici ve oynatıııların ortaya çıktığı yıllar olmuştur. Bu da, video sanatının doğmasına zemin hazırlamıştır (Arapoğlu, 2012: 226). Işste video haberciliğin tohumları da 1960’ı yıllarda atılmıştır. 
Bu yıllarda özellikle ABD'deki yerel televizyonlar, ekonomik koşulların da etkisiyle muhabirlerini, kendi hikayelerini kendileri yazmaları ve yine kendileri çekmeleri yönünde sevk etmiştir. Bu doğrultuda kendi kendine yeten muhabir (self rotation reporter) adıyla bir meslek ortaya çıkmıştır. ABD'de meydana gelen bu değişimler Almanya'da birçok televizyon kuruluşu tarafından takip edilmiş ve uygulanmıştır.

Günümüzde halen devam etmekte olan geleneksel televizyon haberciliğinde haberin toplanma ve yapım aşamalarında muhabir, kameraman, sesçi, montajcı ve elbette metin yazarından oluşan bir grup görev almaktadır. Dünyada video haber ve haberci odaklı ilk haber merkezini, New York ve çevresine yayın yapan New York 1 adlı haber kanalında kuran Michael Rosenblum'a göre (2006) tüm bu işler, tek bir kişi tarafından yapılabilmektedir. Bu da video habercilik olarak adlandırımaktadır (Rosenblum, 2006). Video habercilik, bir habercinin haberi kendi yazdığı, kendi çektiği, kendi montajladığı ve kendi sunduğu bir habercilik biçimidir. Türkçe'ye "Tek kişik orkestra" olarak çevirebileceğimiz One-man band olarak adlandırılan; bu doğrultuda montaj, metin yazarlığı, muhabirlik ve kameramanlık yapan haberciler, 1960 'lardan bu yana ABD yerel televizyonlarında istihdam edilmişlerdir (White, 2001). Rosenblum'a göre bu, "ucuz iş" yaptırmanın yollarından biridir. Çünkü bu istihdam biçiminde haberci ihtiyaç duyulan alanda ikame olarak kullanılmaktadır. Video haberci ise tüm bu alanlarda toptan bir eğitime ve yeterliliğe sahip habercidir (Thorand, 2006: 8). Rosenblum'un aynı zamanda sinemadaki Auteur teorisiyle de desteklediği video habercilik anlayışına göre en iyi hikayeler, ancak tek bir kişinin hayal gücü ve bakış açısıyla oluşturulabilir. Tıpkı Auteur yönetmenler gibi haberci de, haberin tüm aşamalarından sorumlu olmalı ve her aşama onun elinden geçmelidir. Aslında habercinin, haberin her aşamasına dahil olduğu anlayış yayıncılığa çok da uzak değildir. Rosenblum'a göre, yazılı basında halen uygulanmakta olan iş bölümü televizyon haberciliğine de uyarlanabilir niteliktedir. Yazılı basında muhabirler, haberlerini kendileri kaleme almakta, röportajlarını kendileri yaparak gerektiğinde mini ses kaydedicilerini kendileri kullanmakta, pek çoğu haberi kendileri fotoğraflayarak, haberin tüm aşamalarının içinde yer almaktadırlar. Geleceğin haber merkezlerinde muhabirler, kameramanlar ve montajcılar birer haber auteur'ü gibi çok görevli-yetenekli (multi-skilled) olacaktır (Rosenblum, 2006). Mevcut durumda 70-100 kişilik bir televizyon haber merkezi, 5-6 kadar Betacam'in başını beklemektedir. ${ }^{4}$ Bu yine 70-100 kişilik bir gazetenin haber merkezindeki muhabirlerin, ofisteki toplam 5 kaleme talim etmeleri gibidir (Bergman'dan aktaran Thorand, 2006). Oysa mevcut hantal ve verimsiz yapılanmayı aşmak için gerekli teknolojik altyapı, 80’lerden bu yana hazır durumdadır. 80'lerde ana üreticiler Sony, Phillips, Thomson ve Panasonic, ortak bir video standardı belirmek için biraraya gelmiştir. Digital Videocassette'in kısaltması olan DVC, bu firmalar tarafından üretilen hafif ve kolaylıkla taşınabilir video kameralar için ortak standart olarak kabul edilmiştir. DVC zamanla DV, DVCAM ve DVCPRO olmak üzere birbiriyle ilişkili ancak bazı özellikleri farklılaşan üç ayrı formata dönüşerek, bu teknolojiyle donatılmış video kameralar ile kayıt ve depolama ortamlarının genel adı olmuştur. Geliştirilen yeni çipler sayesinde özellikle 90'larda DV formatı, profesyonel yayın formatları ve omuzda taşınan kameralarla yarışır bir duruma gelmiştir. Mini DV kasetlerle kameralar daha da küçüldüğünden, el tipi yarı-profesyonel kameralar (handheld prosumer ${ }^{5}$ camcorders) yaygınlaşmış; görüntü kalitesi kayıt ortamının küçülmesine rağmen artmaya devam etmiştir. 2000'lerde yüksek çözünürlüklü görüntü formatına geçilmesiyle el tipi kameraların görüntü kalitesi artmaya devam etmiştir. Bugün aynı gelişim devam etmekte; ancak manyetik kasetler

\footnotetext{
4 Betacam, Sony tarafından 80'lerde geliştirilen uluslararası televizyon yayıncılı̆̆ında kullanılan görüntü ve ses kayıt formatıdır. Günümüzde halen kullanıımakta olan bu format ve ekipmanları oldukça pahalı olmakla beraber kolayca taşınamamaktadır. Rosenblum bu format ve ilgili ekipmanların hantallığından ve pratik olmayışlarından yakınmaktadır.

5 Prosumer kelimesi, İngilizce "Professional" ve "Consumer" (tüketici-son kullanıcı-amatör) kelimelerinden "pro" ve "sumer" hecelerinin birleştirilmesiyle oluşturulmuş; özellikle video kamera gibi ürünleri sınıfladırmak amacıyla Türkçede "yarı-profesyonel" anlamında kullanılan bir kelimedir.
} 
yerine flash diskler ve hafıza kartları kullanılmaktadır. Bu sayede kasetin içindeki görüntülerin gerçek zamanlı (real time) bilgisayara ve/veya montaj ünitesine aktarılmasıyla kaybedilen süre ve aktarma sırasında yaşanan veri kayıpları da ortadan kalkmıştır. Bu süreçte özellikle Sony'nin PD170, VX2000 ve yüksek çözünürlüklü Z1 modeli halen kullanılan ve kullanıcıları tarafından adlarından övgüyle bahsedilen ve efsane haline getirilmiş kameralar olarak öne çıkmıştır.

Portatif kameraların 1930'lardan günümüze kadar gelişimini araştırmış Michael Rosenblum için özellikle 80 ve 90'larda meydana gelen bu önemli gelişmeler kilit önemdedir. Öyle ki Rosenblum, kamera ve bilgisayar (özellikle dizüstü bilgisayarların montaj yapabilir düzeye yükselmesi) teknolojilerindeki bu gelişimi, Gutenberg'in baskı tekniklerinde yaptığı devrimle eşdeğer görerek, 21. yüzyılın iletişim devrimi olduğunu öne sürmektedir. Bu sayede pratik olmayan geleneksel televizyon haberciliğinin aksine video haberciler kağıt üzerine döktükleri fikirleri rahatça uygulama fırsatına sahip olacaklardır. Her muhabir kendi uzmanlık alanına daha rahat yoğunlaşacak, hikayesini oluştururken daha fazla zaman harcayacak ve araştırmasını derinleştirebilecektir. Bu, Rosenblum'ın gözünde, yeni bir anlatım ve sanat biçiminin doğması demektir. Böyle bir hikaye oluşturma sürecinde hikaye, yine hikayeye hizmet edeceğinden, sunucu, sunum ve biçim ön plana çıkmayacaktır (Thorand, 2006: 10).

\subsection{Video Habercilerin Haber Üretim Süreçleri}

Video habercilikte videolar, belgesel sinemayla özdeş bir bakış açısıyla oluşturulmaktadır. Aslında video habercilik için öne sürülen düşünceler Kameralı Adam (Vertov, 1929) filmiyle ortaya konmuş gibidir. Jean Rouch'un, Vertov'un Sine-göz kuramı ve Robert Flaherty'nin filmlerinden esinlenerek oluşturduğu cinéma vérité (gerçek sinema) yaklaşımı, video haberciliğin dayandığı noktalardan biridir. Bu doğrultuda Vertov'un, bugün anladığımız şekliyle, ilk haber filmlerini çekmiş ve belgesel sinemaya önemli katkılar sağlamış olması, bir habercilik biçimi olarak video haberciliğin anlaşılması ve çıkış noktasını belirlemede bir diğer önemli noktadır. Buradan hareketle Rosenblum'ın, video habercilerin videolarını oluştururken takip etmelerini önerdiği önemli noktalar vardır. Her şeyden önce geleneksel kameramanların aksine, video haberciler üçayak (tripod) gibi kamerayı sabitleyen sistemlerden mahrum olacaklardır. Yine geleneksel bir muhabirin aksine ellerinde, röportaj sırasında notlarını aldıkları not defterleri yerine kameraları olacaklardır. Muhabirin not defteri kendiliğinden kamerası durumundadır. Rosenblum tüm kamera ayarlarının beyaz ve netleme ayarları da dahil olmak üzere otomatik pozisyonda olmasını; istenmeyen otomatik netleme yapılmış ve sallantıya bağı bozuk görüntüleri önlemek için mutlaka geniş açılı objektiflerin ya da dönüştürücülerin kullanılmasını önermektedir. Gerçekçilik her zaman ön planda tutulacağından ortamdaki ışığa ek ışıklandırma ve hatta çok gerekmedikçe kamera üzerindeki ışık bile kullanılmamalıdır. Haberci atmosferi hissetmek için çekimden 20 dakika önce ortamda zaman geçirmeli, olay örgüsü planlamalı ve olayları sekanslara toplayacağı tek tek sahneler halinde bölmelidir. Rosenblum, etkili ve iyi bir video haber oluşturmak için beş basit çekim ölçeği tanımlanmıştır:

1. Eylemin yakın plan çekimi

2. Yüzlere yapılan yakın çekim

3. Tüm sahnenin geniş plan çekimi

4. Omuz (amors) plan çekimler

5. Diğer-ters bakış açıları 
Rosenblum New York 1 haber kanalında başlattığı video habercilik odaklı habercilik sistemini Voice of America, The New York Times, BBC, German Public Tv gibi medya kuruluşlarına sunmuştur. Rosenblum, ABD Başkan Yardımcılığı ve Demokrat Parti başkan adaylığı bulunan eski senatör ve Oscar ödüllü belgesel yapımcısı Al Gore'un sahibi olduğu, kullanıcı temelli içerik (user generated content) üreten Current TV'nin kuruluşunda görev almıştır (Clark, 2009). Rosenblumtv, Nyvs ve Rosenblum-Institute adlı web sitelerinde video habercilikle ilgili çevrimiçi bilgiler ve dersler vermektedir. New York Video Okulu'nun kurucusudur.

İngiltere'de alanın bağımsız öncüsü olarak David Dunkley Gyimah gösterilmektedir. 25 yıldan fazla bir süre önce televizyon muhabirliğiyle işe başlayana Gyimah, başta BBC'nin Dünya Servisi olmak üzere, Amerikan ABC News, İngiliz Channel 4 ve ITV olmak üzere belli başlı medya kuruluşlarında çalışmıştır. Gyimah İngiltere'de resmi olarak tanınmış ilk video haberci olma özelliğine sahiptir. Gyimah, çalışmalarında sinema ve fotoğraf sanatından beslendiğini belirtirken, tüm video habercilere de bu yönde tavsiyelerde bulunmaktadır. Video haberciliğe eşdeğer olarak öne sürdüğü cine-journalism, video haberciliğin hikaye anlatmada sinemaya daha çok yaklaşacağı yönünde kendine ait bir öngörüdür. İngiltere'de alandaki bilinirliğine paralel olarak özellikle lüks otomobil firmaları tarafından kendisine video haber biçiminde viral reklamlar yaptırılmaktadır.

Gyimah internetin sunacağı olanakları 90'larda keşfetmiş bir gazetecidir. Gyimah internetin yayılmasıyla birlikte dışardan-bağımsız çalışmakta olduğu birçok televizyon kuruluşuyla yollarını ayırmış, internet yayıncıı̆ğına yoğunlaşmıştır. Video habercilikle ilgili hazırladığı videolarda internetin kendisi ve birçok video haberci için doğal yaşam alanı olduğunu vurgulamaktadır ${ }^{6}$. Video habercilikle ilgili üniversitelerde seminer ve dersler veren Gyimah, İnternet Sonrası Gazetecilikte Hikaye Anlatımı konulu doktora tezi üzerinde çalışmaktadır (Gyimah, 2010). Gyimah, ulusal ve uluslararası birçok önemli ödül kazanmıştır.

İngiltere'de ayrıca 2001 yılından itibaren BBC, bölgesel temsilciliklerindeki muhabir ve kameraman kadrolarını video haberciye dönüştürmeye başlamıştır. 2005 itibariyle kurumda 600'den fazla video haberci istihdam edilmiştir (BBC Press Office, 2005). BBC Güneydoğu bölgesi video habercilerinden Peter Whittlesea, BBC'nin çevrimiçi habercilik okulunda bir gününü aktarmıştır. Whittlesea prodüktöründen gelen iş emirlerine göre hikayesini oluşturmakta, Sony Z5 model yüksek çözünürlüklü kamerasıyla çekimleri yapmakta ve dizüstü bilgisayarına kurulu olan video montaj yazılımıyla görüntülerini düzenlemektedir. Olası işler İngiltere'nin güneydoğusunda geniş bir alanı kapsadığından, işlerini evden yürütmektedir. Güne prodüktörünün telefonuyla başlamaktadır. Gelen iş emrine göre hemen kamyonetiyle çekim yapacağı alana hareket eden Whittlesea, video haberci olmanın en güzel taraflarını, bir telefonla harekete geçmek, herhangi bir kişiyi ya da ekibi beklemek zorunda olmamak, tüm organizasyonu bürokrasi olmadan kendi başına halletmek olarak sıralamaktadır. İşin en önemli noktaları ise, hikaye oluşturma ve oluşturulan hikayenin uygulama kısmında, yani çekim aşamasında hata yapmamaktadır. Yapılacak hatalar bazen montajda bile düzeltilemeyebilir. İşin yazınsal-edebi kısmıyla ilgili çok iyi düşünülmesi gerektiğini belirten Whittlesea, röportajlarda soruları önceden hazırladığı gibi, çekim sırasında anlatılanlara göre yöneltebildiğini de ifade etmektedir. Her ne olursa olsun, çekim sırasında görüşme yapılan kişinin çok iyi dinlenmesi şarttır. Yaptığı çekimi montajlayıp öğle bültenine yetiştirmesi için yalnızca bir saati vardır. Görüntülerin montajını ve görüntülere eşlik eden haber metninin seslendirme kaydını kamyonetinin arkasında yaparak mobil internet(3G) ile haber merkezine göndermektedir (BBC College of Journalism, 2013). 


\subsection{Video Haberciliği Bir Disiplin Haline Getirme Çabaları}

San Francisco State Üniversitesi Fotomuhabirliği bölüm başkanı olan Kenneth Kobre, fotoğrafçılık üzerine kaleme aldığı birçok kitaptan sonra, Videojournalism adlı kitabıyla, bu habercilik biçiminin geniş bir tanımını vermeye çalışmıştır (Kobre Guide, 2013). Kobre ve Lazar (2009), video habercilerin etkili haber metni oluşturmalarına yardımcı olacak 10 ipucu sıralamıştır.

\section{Sürükleyici bir hikaye bulmak,}

haberciliğin temelidir. Kobre'ye göre çoğu haberci sadece kamerayı çalıştırıp röportaj yaptığı kişiye doğrultup, ondan kendisini anlatmasını beklemektedir. İzleyicilerin çoğu bu videoların sonunu beklememektedir. Bu noktada Aristo'nun klasik dramatik unsurlarını hatılatan Kobre; iyi bir plan, ana tema, karakterler, diyaloglar, ritm ve çatışmayla birlikte dramatik yapıyı oluşturan doruk noktası, düğüm ve çatışma gibi unsurların da iyi bir hikaye oluşturmada tek başına yardımcı olamayacaklarını öne sürmüştür. Gerçek hayatın, klasik Aristo mantığı hikaye yapısı kadar düzenli olamayacağını belirten Kobre, muazzam görüntüler ve unutulmaz sözlerle unutulmaz anların yakalanmasının iyi ve sürükleyici bir hikaye oluşturmada etkili olacağını vurgulamıştır.

\section{Bir karakteri merkeze almak,}

iyi bir karakter oluşturmada önemli ipuçlarından biridir. Seyircilerin empati kurabilecekleri bir karakterin sorunları ve eğilimleri hikayeyi sürükleyecektir. Bazı insan hikayeleri her zaman resmin geneli için seyirciye fikir verecek ve çıkarımlar yapmasını sağlayacaktır.

\section{Röportaj yapma becerilerini geliştirmek,}

iyi bir hikaye ve hikayeci için önemlidir. Röportaj yapılan kişiye adı ve durum hakkında sorular sormak bir röportaj değildir. Özellikle dramatik gerilimi doruğa çıkaracak sorular sormak hikayeyi ileriye taşıyacaktır. İyi bir röportaj yapabilmek aynı zamanda iyi bir dinleyici olmayı gerektirir. Bazen hemen cevap vermemek ya da yeni bir soru yöneltmemek akıllıca olabilir. Çoğu amatör muhabir sessiz geçen anları bir hata olarak görmektedir. Bazen konuşma arasında verilen aralar iyi bir dramatik etki yaratmaya kesinlikle yardımcı olacaktır.

4. Daha iyi bir habercilik için, farklı bakış açıları kovalamak,

hikayeye konu olan kahramanınız ne kadar çekici olursa olsun, yine de temel gerekliliktir. Bu yüzden bütün konuyu enine boyuna ortaya koyacak bir görüşme-röportaj planı ve listesinin hazırlanması şartır. Böyle bir plan sonunda, kimin neyin ya da hangisinin kameranın önünde olması gerektiğine karar vermek kolaylaşacaktır. Dolayısıyla gazeteciliğe has nesnellik idealini gerçekleştirmek adına tüm hikayeleri ekrana taşımak gibi bir intiyaç da duyulmayacaktır. Önemli olan, farklı ancak sonunda haber için yeterli bakış açılarını biraraya getirip sunabilmektedir.

\section{Duvarkağıtlarını ve arkaplan resimleri sökerek fazlalıkları atmak,}

hem hikayenin sürükleyiliği hem de görsellik adına önemlidir. Karakterin konuşurken, yürürken, bir şeylerle uğraşırken ek çekimlerinin yapılması ve özellikle röportaj sırasında bu görüntülerin aralara serpiştirilmesi doğru bir yöntem değildir ve çoğu izleyici bu tip görüntülerden 
sıkılmakta ve mekanik bulmaktadır. Kobre'ye göre bir videoyu etkili kılan şey, karakterlerin sesleri duyulduğu anda tam olarak ne yaptıklarının verilmesi ve gösterilmesidir. Çekimden önce planlama ve sonrasında montajda sahnelerin belli bir hiyerarşiyle birleştirilmesi görüntüleri sinemasal anlatıya yaklaştıracaktır.

\section{Anlatmak yerine göstermek,}

görsel bir mecra olarak videonun ruhuyla örtüşmektedir. Buna rağmen, yukarıda bahsedilen fazladan çekimler de çoğu zaman izleme eylemini zorlaştırır. Neyin gösterileceğini anlayabilmek röportaj yapılacak kişilerle öngörüşme yapmak iyi bir çözüm olacaktır. Karakterlerin içinde bulundukları durumları tanımladıkları çekimlerden çok neler yaptıklarının gösterildiği görüntüler yakalamak hedeflenmelidir.

\section{Kendine yeten bir video hazırlamak,}

videoyu gereksiz anlatım, yazı, resim, harita ve grafik gibi unsurlarla boğmamak video haberciliğin önemli kurallarından biridir.

\section{Doğal seslere odaklanmak,}

videonun sesleri de kapsadığını unutmamaktır. Video görsel bir mecra olsa da bu hikayeye katkıda bulunarak görüntüleri tamamlayacak doğal sesleri duymayacağımız anlamına gelmez. Duyduklarımıza gördüklerimizden daha fazla inandığımız göz önüne alınırsa, ortam sesleri ve görüntüyü tamamlayacak seslerin hikayeyi ileriye taşıyacağını söylemek yerinde olacaktır.

9. Sadece sahne boyunca değil; sahneden önce ve sonrasında da çekmek,

hikayenin bütünlüğünü sağlayacaktır. Çoğu video haberci, videolarının başına bir giriş/ kapak çekimi yapar. Ancak çoğu zaman bu, hikayeden bağımsız ve kopuk anları betimlemektedir. Gerçek bir hikayenin, doğal olarak bir öncesi ve sonrası vardır. Bu anlar doğru düzenlenirse kronolojik ve süregiden bir hikaye oluşturulmuş olacaktır. İyi bir hikaye dönüm noktalarına sahiptir. Başka bir deyişle süregelenle sonrasını ayıran kesin bir çizgiden ibarettir.

\section{0. Çok daha iyisi için ilham almak,}

hiçbir şey yapılamıyorsa hayat kurtarabilir. Günümüzdeki koşullar dikkate alındığında her ne kadar video dünyası, film ve televizyondan ayrışarak farklı bir yöne doğru ilerliyorsa da, film ve televizyon tarihini yadsımak mümkün değildir. Film ve televizyon uzun bir geçmişe sahiptir. Özellikle filmlerden ve belgesel sinemadan öğrenilecek çok şey vardır. Soran ve soruşturan bir izleme, iyi bir video haberci olma yolunda önemlidir. Bir filmde açılar, çerçeveleme, diyaloglar ve sessizliğin kullanımı video habercinin dikkat etmesi gereken noktalardır. Kamera hareketleri ve montaj teknikleri üzerinde sürekli pratik yapılmalıdır. Her ne kadar video yeni bir dil olsa da, sinemanın anlatım olanaklarından faydalanması kaçınılmazdır (Kobre ve Lazar, 2009).

Kobre ve Lazar'ın tanımladığı bu 10 ipucu ABD'de kamu yayıncılığı yapan PBS'in video haberciler için sunduğu pratik bilgiler bölümünde sunulmuştur. 


\subsection{Türkiye’den Video Habercilik Örnekleri}

Çalışmanın bu bölümünde Anadolu Ajansı ve Hürriyet'in internet sitelerinin video bölümlerinde yer alan birer video haber, bu bölüme kadar ortaya konan video habercilik kavramı ve biçimi çerçevesinde incelenecektir.

Anadolu Ajansı'nın internet sitesinde 25 Nisan 2015'te yayınlanan "istanbul'da Erguvan Zamanı" (2015) başııkı video ile ilgili bilgilerde, yayına verildiği tarih ve saat dışında haberi hazırlayan muhabirin ismi yer almamaktadır. Aynı durum sitenin genelinde tüm video haberlerde göze çarpan bir durumdur. Video boyunca bir muhabir ya da sunucu ekranda görünmemektedir. Kameramanın ve görüntüleri kurgulayanın kim olduğu da, gerek videoda gerekse video ile ilgili bilgilerde yer almamaktadır. Video boyunca görüntülere sadece bir erkek tarafından yapılan seslendirme eşlik etmektedir. Bu kişinin haberi yapan, yazan ve aynı zamanda görüntüleri de kaydederek kurguladıktan sonra yayına servis eden kişi olup olmadığı bilgisi de belirsizdir. Video ekranının hemen yanında, baharı müjdeleyen erguvanların boğazın her iki yakasında şehre güzellik kattığı bilgisi verilmiştir. Bu metin, haberin başlı̆ı ile birlikte seslendirmesi yapılan haber metninin de birebir ilk paragrafını oluşturmaktadır. Seslendirmenin bu bölümünde, sabit üç ayak üzerine yerleştirilmiş kamerayla kaydedilmiş, erguvan ağaçlarının arasından boğazı ve boğaz köprülerini gören görüntüler verilmiştir. Her sabit görüntü, yaklaşık üçer saniye ekranda tutulmuş; genel boğaz manzarası planlarından erguvan dallarını merkeze alan yakın plan çekimlerine doğru olmak üzere birbirlerine eklenmiştir. Seslendirme metninin devamında, erguvan ağaçlarının İstanbullular ile birlikte kente gelen yabancı turistleri de heyecanlandırdığı aktarılmıştır. Ne var ki, metinde verilen bu bilgiyi destekleyecek herhangi bir röportaja yer verilmemiştir. Metin, erguvan ağaçlarının en iyi şekilde Eminönü, Beşiktaş ve Üsküdar'dan yapılan tekne turlarıyla görülebileceği bilgisini vererek devam etmektedir. Bu bölümde yine bilgiyi desteklemesi açısından tekne turuna çıkmış bir kişi ya da tekne sahibi ile yapılabilecek herhangi bir röportaja yer verilmemiştir. Yine metnin bu kısmında ya da devamında, verilen bilgiyi destekleyen görüntülere yer verilmemiştir. Görüntüler haberin başında yer alan genelden özele ya da özelden genele ve hangi semt ya da yere ait olduğu belli olmayan görüntülerin üçer saniyelik geçişlerinden ibarettir. Metin, Avrupa yakasında Beşiktaş'ta bulunan Yahya Efendi Dergâhı'ndan başlayarak Yeniköy'e kadar devam eden bir alanda erguvanlara rastlanabileceğini ve yoğun olarak da Rumeli Hisarı'nın sağında ve solunda görülebileceğini aktarırken, görüntülerin belirtilen mekanları tam olarak verip vermediği çerçeveleme sorunlarından ötürü anlaşılamamaktadır. Benzer bir sorun ve görüntü montajı metnin devamında Anadolu yakası için verilen bilgiler için de geçerlidir. Videoda doğal ortam seslerine sınırlı ve konuyu desteklemekten uzak bir biçimde, seslendirmenin arasında yer verilmiştir. Videonun uzunluğu başlangıçtaki Anadolu Ajansı jeneriği de dahil olmak üzere 59 saniyeden oluşmaktadır.

Hürriyet gazetesinde 4 Mayıs 2014'te yayınlanan Fikirtepe'de Tek Başına başlıklı haber, gazetenin internet sitesinde "Fikirtepe İnatçısı" (Alagöz, 2014) olarak yer almıştır. İstanbul'daki kentsel dönüşüm bölgelerinden biri olan Fikirtepe'de inşaat şirketleri, bölgedeki hak sahiplerinin büyük bir bölümüyle yıkım için anlaşmaya varmış, sadece bir konut sahibiyle anlaşmaya varamamıştır. Bu yüzden 31 dönümlük arazide bulunan tüm eski yapılar yıkılmış; arazinin tam ortasında, anlaşma sağlanamayan A.D. isimli şahsın eski yapısı kaldığından dönüşüm projesine başlanamamaktadır. Bir gazete haberi olarak, yine gazetenin bir bayan muhabiri tarafından hazırlanan haber için, gazetenin internet sayfasına haberle ilgili bir video da yerleştirilmiştir. Sağ üst köşede Doğan Haber Ajansı logosunun yer aldığı görüntülerin toplam uzunluğu 1 dakika 17 saniyedir. Video, 31 dönümlük arazinin tam ortasında yer alan eski yapıya çok hızlı bir yakınlaştırma (zoom-in) ve hemen ardından hızlı bir uzaklaştırma (zoom-out) ile başlamakta; bunun sonunda sağa doğru 
çevrinmeyle ilk kesmeye bağlanmaktadır. Açık arazide ve yoğun rüzgar altında gerçekleştirilen bu çekim sırasında kamera omuz üzerinde olduğundan yoğun rüzgarın etkisiyle çerçevelemede sorunlar görülmektedir. Görüntüye doğal ortam sesi eşlik ederken, kamera mikrofonunda rüzgarlık olmayışından ötürü, aşırı rüzgar seste rahatsız edici patlama ve istenmeyen gürültülere neden olmaktadır. Bu ilk sahne boyunca görüntülere eşlik eden bir seslendirme yoktur. Videonun başından sonuna kadar, ekranın alt kısmında "hürriyet tv" logosu ve haberin konu başlığının yer aldığı bilgilendirme grafiği (KJ) sabit bir şekilde verilmektedir. Illk sahnenin sonunda bir röportaja kesme yapılmıştır. Röportaj yapılan yaşlı adam, arazinin tam ortasındaki binanın verilmediğini ve bölge halkının bu yüzden mağdur olduğunu anlatmaktadır. Röportaj yapılan kişinin yüzü herhangi bir teknikle gizlenmemiş ve açıkça verilmiştir. Buna rağmen bilgilendirme grafiğinde, kişinin adı ve haberle ilgisi olabilecek unvanları verilmemiştir. Röportaj yapılan kişi, konuyla ilgili bilgi vermeye devam ederken, arazi ve yıkıma konu olan eski yapı ile ilgili genel ve yakın plan başka görüntüler verilmektedir. Geri planda, röportaj yapılan kişiyi "hı hı - hmmm" gibi nidalarla onaylayan bir erkek sesi duyulmaktadır. Aynı kişi kamera arkasından röportaj yapılan kişiye konuyla ilgili soru da sormaktadır. Bu kişinin kameraman olduğu düşünülmektedir. Haber boyunca ve haberin yer aldığı internet sayfasında bu bilgi verilmemektedir. Haberi gazete için hazırlayan ve yazan muhabir ile videoyu kayda alan kişi birbirlerinden farklıdır. Röportaj veren kişi, bu durum karşısında mahalle sakinlerinin artık isyan noktasına geldiğini ve ayaklanma çıkacağından dem vururken, diğer mahalle sakinlerinden herhangi biriyle, bu savı destekleyecek yan röportajlara yer verilmemiştir.

\subsection{Video Habercilik: Olanaklar}

90'larda görüntü kayıt cihazları ve bilgisayarlardaki teknolojik gelişmelerle internetin ortaya çıkışı yeni bir gazetecilik biçimi olarak video haberciliğin önünü açmıştır. $O$ yıllarda yayın için hâlâ televizyon kanallarına bağımlı olan video haberciler, internetin 2000'li yıllarla başlayan hızlı gelişimi; Web 2.0, sosyal medya ve ağlar, kablosuz ağlar ve mobil teknolojinin de gelişimiyle televizyon yayıncılığına bağımlı olmaktan kurtulmuştur. Video günümüzde haberle birlikte başlıca eğlence haline gelmiştir. Bugün internetin sunduğu olanaklardan geniş ölçüde yararlanan ve ortaya çıkışı 90'। yıllara rastlayan yurttaş gazeteciliği ve bu eksende yapılan tartışmaların, video habercilikle paralel olarak sürdürülmesi gerekli görünmektedir. İnternet ve mobil teknolojinin gelişimiyle yurttaş gazeteciliğinin de video haberciliğe doğru yöneldiği gözlemlenmektedir. Her ikisi de geleneksel medyaya güvenin azaldığı bir ortamda yeni bir anlayış olarak ortaya çıkmıştır. Biri profesyonel diğeri amatör bir çaba olarak görünse de birbirlerinden beslendikleri ve ortak beslendikleri sinema ve televizyon geleneği, her ikisini de birbilerinden tamamen bağımsız olarak değerlendirmelerini güçleştirmektedir. Son beş yılda dünyanın dört bir yanında meydana gelen toplumsal hareketlerde halk arasından kişilerin çektiği videoların internet ortamında hızla dolaşıma sokulmasıyla herkesin gazeteci, muhabir ve haberci olabileceği bir ortamın oluştuğu görülmektedir. Hızlı üretim hızı dolaşım ağlarıyla birleştiğinde video, günümüzün en hızlı tüketilen görsel ve işitsel ürünü olarak öne çıkmaktadır. Televizyon izleyicisinde günden güne azalma devam etmektedir. Yine de bu hız geleneksel medyanın dikkatinden kaçmamıştır. Başlangıçta yerel televizyonlar için maliyetlerin düşmesi ve hızın artması yolunda gözardı edilemez olanaklar sağlayan video habercilik, bu yönüyle geleneksel medyanın da ilgi alanına girmiştir. Geleneksel medyada zaman özellikle paraya denk geldiğinden, video habercilik etkin zaman yönetimi ve maliyetlerin düşürülmesi yönünden fırsatlar sunmaktadır.

Video haberciliğin anlatım dili, biçim ve uslup olarak sinemaya, özellikle belgesel sinemadan beslenmesi ve bu çerçeveye yaslanması; bu çalışmanın Video Habercilerin Haber Üretim Süreçleri bölümünde ifade edildiği gibi video habercilik, belgesel sinema ve bir alt tür olarak cinéma vérité (gerçek sinema) arasında metinlerarası bir ilişkiyi mümkün kılmaktadır. Vertov'un 
da (2007) belirttiği gibi, "yeni haber filmi anlayışında her şey vardır. Hayat karmaşına giren iki şey:

1) İnsan gözünün görsel dünya sunumuna meydan okuyan ve kendi 'görüyorum' (İngilizce'de 'I see', Latince'de 'Video') versiyonunu sunan sine-göz,

2) bu şekilde ilk defa görülen hayat-yapısının anlarını düzenleyen kinok-kurgucu." (Vertov, 2007:21)

Vertov'un 1920 'lerde ortaya koyduğu gibi, günümüzde de video habercilik bu ikisini aynı kişide toplamaktadır. Vertov'da ifade bulan sinema ve haber filmi eksenli bu metinlerarası ilişki, disiplinlerarası ilişkiyle beslendiğinde, özellikle alanda klasik-geleneksel programlarda eğitim gören öğrenciler için video ve video habercilik, sektörde yer edinmek adına yeni bir giriş kapısı olabilir.

\subsection{Video Habercilik: Sorunlar}

Söz konusu alanda yetişmiş profesyonel insan gücününün olmayışı özellikle gelişmekte olan ülkeler için önemli bir sorun olarak göze çarpmaktadır. Öte yandan bu ülkelerde, profesyonel olarak video habercilik yapmak isteyenlerin önünde duran maliyetler, büyük bir sorun olarak belirmektedir. Olanaklar bölümünde tartışıldığı üzere geleneksel medya düzeninde maliyetlerin düşürülmesi yönünde işverenler için önemli bir fırsat olarak görünen video habercilik, bir sömürü biçimine dönüşebilme potansiyeline de sahip görünmektedir. Henüz kavram girmemiş olsa da, "ne iş olsa yaparım/yaptırıım" gibi bir anlayışın neredeyse her sektöre işlediği ülkemizde, görünürde geleneksel haber hazırlama metodunda yer alanların tamamını kapsayan bir iş gibi görünen video habercilikle ilgili olarak, geleneksel medya aktörlerinin bu alana kafa yormaları şaşırtıcı olmayacaktır. Nitekim yakın zamanlarda Hürriyet gazetesi yönetim kurulu başkanı Vuslat Doğan Sabancı, 2011 yılında katıldığı bir televizyon programında, Hürriyet'in gelecekteki organizasyon yapısının, yönetim kurulunda hararetle tartışılan bir konu olduğunu ifade etmiştir. Organizasyon yapısının mecranın dağıtımından çok içerik üretimine göre planlanacağını belirten Sabancı; artık bir gazetecinin bir haberi yazma, o haberin videosunu çekme, aynı zamanda montajlama ve son olarak bunu yayına sokma gibi faaliyetleri birarada yürütmesine yönelik tartışmaların yapııması gerektiğini belirtmiştir (Gelecek Gündemde, 2011). Buna göre sektörün intiyaç duyabileceği nitelikli video habercilerin yetişmesi durumunda, kendini bu doğrultuda yetiştirip dönüştürememiş muhabir, sunucu, kameraman ve montaj elemanlarının süreçten olumsuz etkilenmesi olasılıklar dahilindedir. Ne var ki kavram, Türkiye'de henüz tartışmaya açılmamış ve bakir bir alan olarak kalmıştır. Türkiye'de ayrıca gelişmiş ülkelere kıyasla bu yöntemle habercilik yapma önünde ciddi resmi ve bürokratik engeller olduğu da aşikârdır. Haberci olabilmek için basın kartı sahipliği zorunluluğu en önemli engel durumundadır. Bu noktada yurtdışında oldukça yaygın olan, video ve internet haberciliğinin doğasına uygun nitelikteki freelance-serbest muhabirlik ülkemizde bu doğrultuda yaygınlaşmamıştır. Özellikle ülkemizde son yıllarda internet ile ilgili yeni ve sınırlayıcı hukuki düzenlemeler, bağımsız internet habercilerin önüne yeni engeller koymaktadır.

\section{Sonuc}

Video içerikler, günümüzde giderek öne çıkmaktadır. Dünyada ve ülkemizde halen televizyon en çok takip edilen mecra olarak görünse de, internet ve özellikle mobil internet kullanımı giderek artmakta, video içeriği kapsayan trafik yoğunluğu göze çarpmaktadır. Bir eğlence ve haber alma aracı olarak video diğer içeriklerden bu yönüyle ayrılmıştır. Mobilleşen dünyada yeni bir habercilik biçimi olarak video habercilik, her ne kadar ülkemizde ele alınmamış olsa da; tüm 
haber ajanslarıyla birlikte, gazeteler, televizyon istasyonları ile bağımsız internet sitelerinde haber videolarının sergilendiği sayfalar ve galeriler olduğu gözlemlenmiştir. Ne var ki, buralarda yer alan video içeriklerin, özellikle Anadolu Ajansı ve Hürriyet gazetesinin internet sitelerinde yer alan iki ayrı videonun incelenmesi sonucu ortaya çıkan veriler dikkate alındığında, bu çalışma kapsamında ortaya konan video habercilik anlayışı ve biçiminden oldukça uzak olduğu ileri sürülebilir. Salt-ham görüntülerden oluşan içerikler planlı bir akış ve montajlamayla birlikte, video haberciliğin temel çıkış noktası olan özgün bir bakış açısı ve bir hikaye anlatmaktan tamamen uzaktır. Kullanıcının artık içerik üretimine dahil olduğu günümüzün yeni medya ortamında haberi, konuyu ve hikayeyi böylesine yönlendiren bir kişisel ve özgün bir bakış açısı kullanıcı, izleyici ve takipçiler için gerekli midir ya da tercih edilir midir; bu da, konuyla ilgili bir alımlama çalışmasına kaynaklık edebilir bir araştırma sorusu olabilir niteliktedir.

İletişim fakültelerinin ve bu okullardan mezun olanların çoğaldığı günümüzde, öğrencilerin yeni medya araçları ve internet sonrası gazetecilik biçimlerine yönelik bir bakış açısı kazanmış olmaları gerekmektedir. Yönlendirmelerin bu doğrultuda yapılması gerekli görünmektedir. Ülkemizde akademik tartışmalar içinde hatırı sayılır bir yer edinmiş yurttaş gazeteciliğinin tartışma alanının video boyutunda genişletilmesi ve bu tartışmalara amatör ve/veya profesyonel bir uğraş olarak video haberciliğin de dahil edilmesi gerekli görünmektedir.

Günümüzde internet ve sosyal medyanın kullanım alanın genişlemesiyle birlikte geleneksel medyanın geleceğine yönelik sorunların ortaya konduğu geniş bir literatür mevcuttur. Bütün bunlar dikkate alındığında amatör ya da profesyonel alternatif gazetecilik biçimlerine yönelik tartışmaların önünün açılmasına her zamankinden daha fazla ihtiyaç duyulmaktadır. Bunun, gazetecilerin olduğu kadar okurlar ve izleyicilerle birlikte, daha özgür ve özgün bir basın adına öğrencilerin ve akademisyenlerin de ortak sorumluluğu olduğu düşünülmektedir.

\section{Kaynakça}

Alagöz, Gülistan (2014). “Fikirtepe İnatçısı”. http://www.hurriyet.com.tr/ekonomi/26348646.asp. Erişim tarihi: 25.04.2015.

Arapoğlu, Fırat (2012). “Yeni Bir İfade Olasılığı: Güncel Sanatta Video'nun Radikal Dili.” Yeni Medya Ve, Deniz Yengin (der.) içinde. İstanbul: Anahtar Kitaplar. 225-236.

Barnouw, Erik (1990). Tube of plenty: The evolution of American television. New York: Oxford University Press.

"BBC hosts European video journalism conference." (2005). http://www.bbc.co.uk/pressoffice/pressreleases/ stories/2005/07_july/01/vj.shtml. Erişim tarihi: 05.01.2014.

Bordwell, David ve Thompson, Kristin (2012). Film Sanatı. Ertan Yılmaz ve Emrah Suat Onat (çev.). Ankara: De Ki.

Castells, Manuel (2010). The Rise of the Network Society. West Sussex: Wiley-Blackwell.

Cavalier, Jean Jacques (2004). Dünden Bugüne Medya ve İletişim Teknolojileri. Mete Çamdereli (çev.). İstanbul: Salyangoz Yayınları.

"Cisco Visual Networking Index: Forecast and Methodology, 2012-2017."(2013). http://www.cisco.com/en/ US/solutions/collateral/ns341/ns525/ns537/ns705/ns827/white_paper_c11-481360_ns827_Networking_ 
Solutions_White_Paper.html. Erişim tarihi: 05.01.2014.

Clark, Jayne (2009). "Travel Channel offers a video 'boot camp' for aspiring journalists.” http://usatoday30. usatoday.com/travel/news/2009-04-23-video-training_N.htm. Erişim tarihi: 05.01.2014.

Covey, Sean (1998). The 7 Habits OF Highly Effective Teens. New York: Simon \& Schuster.

"DEC's Blockbuster: The PDP-8." (2000). http://www.computerhistory.org/revolution/minicomputers/11/331. Erişim tarihi: 05.01.2014.

Elen, Richard (2003). "TV Technology 10. Roll VTR.” http://www.screenonline.org.uk/tv/technology/ technology10.html. Erişim tarihi: 05.01.2014.

Gyimah, David Dunkley (2010). “About.” http://www.viewmagazine.tv/about.html. Erişim tarihi: 05.01.2014

"İstanbul'da Erguvan Zamanı." (2015). http://www.aa.com.tr/tr/mod/video-galerisi/2018089/istanbuldaerguvan-zamani. Erişim tarihi: 25.04.2015

Kobre, Ken (2013). “About Us.” http://kobreguide.com/about_us/. Erişim tarihi: 05.01.2014.

Kobre, Ken ve Lazar, Jerry (2009). "10 Tips for Dramatically Improving Your Videojournalism Stories.” http:// newshourtc.pbs.org/newshour/thenews/foreducators/productiontips/10\%20Tips\%20for\%20Making\%20 Videos.pdf. Erişim tarihi: 05.01.2014

Kumparak, Greg (2014). "YouTube Can Now Play Videos At A Buttery 60 Frames Per Second.” http:// techcrunch.com/2014/10/29/60-fps-youtube/. Erişim tarihi: 23.04.2015.

"Medyanın Dönüşümü - Vuslat Doğan Sabancı." (2011). http://gelecekgundemde.org/LiderUzmanlar/ Medyanin-Donusumu-Vuslat-Dogan-Sabanci-6.aspx. Erişim tarihi: 05.01.2014.

Mutlu, Erol (2004). İletişim Sözlüğü. Ankara: Bilim ve Sanat.

Öztürk, Zeynep (2013). “YouTube'da canlı yayın yeniliği!” http://www.chip.com.tr/haber/youtube-da-canliyayin-yeniligi_44255.html. Erişim tarihi: 05.01.2014.

"Regional TV Video Journalist." (2013). http://www.bbc.co.uk/programmes/p014zy08. Erişim tarihi: 05.01.2014.

Rosenblum, Michael (2006). "Who We Are." http://www.rosenblumtv.com/about/michael-bio/. Erişim tarihi: 05.01 .2014

Stuart, Keith (2014). "Battlefield Hardline ushers in era of smooth YouTube trailers." http://www.theguardian. com/technology/2014/jun/27/battlefield-hardline-youtube-trailers-games. Erişim tarihi: 23.04.2015.

Şimşek, Ali (2005). Yeni Orta Sınıf. İstanbul: L\&M Yayınları.

“Televizyon Kültürü Ölüyor mu?” (2013). http://genelgundem.com/haberler/2943.aspx. Erişim tarihi: 05.01.2014.

Thorand, Gregor (2006). Development of Guidelines for Successfully Applying Video Journalism to Local and Regional Newsrooms. https://www.yumpu.com/en/document/view/23871979/development-of-guidelinesfor-successfully-applying-video-. Erişim tarihi: 05.01.2014

\footnotetext{
${ }^{\star \star \star} A$ mazon ve benzer sitelerde kitap olarak görünmekte. Ancak şahsın kendi isteğiyle ilgili sitelerde
} 
yayınlandığı belirtilmektedir. Kaynağa, yukarıda verilen pdf linki üzerinden erişilmiş ve kullanılmıştır. http://www.amazon.com/Development-Guidelines-Successfully-Applying-Journalism/dp/B006YVUF8Q http://www.abebooks.com/Development-Guidelines-Successfully-Applying-Video-Journalism/1112025242/bd Tokgöz, Oya (2012). Temel Gazetecilik. Ankara: İmge Kitabevi.

TRT 4K yayına geçti. (2015). http://www.milliyet.com.tr/trt-4k-yayina-gecti--teknoloji-2019115/. Erişim tarihi: 23.04.2015

Vertov, Dziga (Yön.) (1929). Kameralı Adam [Sinema Filmi].

Vertov, Dziga (2007). Sine-göz. Ahmet Ergenç (çev.). İstanbul: Agora Kitaplığı

Video. (2014). http://www.oxforddictionaries.com/definition/english/video. Erişim tarihi: 05.01.2014

White, Ted (2001). Broadcast News Writing, Reporting and Producing. Boston: Focal Press.

YouTube 4K video yayınına hazırlanıyor. (2014). http://www.ntv.com.tr/arsiv/id/25489618/. Erişim tarihi: 23.04.2015.

17 yılda internetin dengeleri değişti. (2013). http://www.ntv.com.tr/arsiv/id/25472954/. Erişim tarihi: 23.04.2015.

İlgili Siteler

http://www.aa.com.tr/en/mod/video-gallery

http://www.mynet.com/video/

http://en.cihan.com.tr/video/

http://cyndygreen.wordpress.com/

http://www.gelecekgundemde.org/

http://www.theguardian.com/guardian-masterclasses/video-journalism

http://kobreguide.com/

http://storyhunter.tv/

http://www.viewmagazine.tv/

http://www.vjmovement.com/

http://www.nyvs.com/

http://www.rosenblum-institute.com/content/index.htm

http://www.rosenblumtv.com/

http://www.tvdawn.com/ 